\title{
RAPORTUL DE DREPT CIVIL - MOSTRĂ DE NOSTALGIE IDEOLOGICĂ ANALITICĂ
}

\section{Paul Vasilescu*}

\begin{abstract}
O}$ datină a doctrinei de drept civil român a devenit și aceea de a analiza „raportul juridic civil” și „dreptul subiectiv” distinct, subliniind totodată raportul de la întreg la parte dintre acestea. Curiozitatea ne-a determinat să cercetăm originile acestei viziuni insolite. Astfel, s-a întrezărit, ridicându-se la orizont, din nou, dreptul socialist în care trebuie să te înfunzi pentru a redescoperi rădăcinile unui concept atât de răspândit, reluat, bun în a explica tot, chiar și în ziua de azi: raportul juridic civil.

Cuvinte cheie: drept civil român, drept subiectiv, drept socialist, drept sovietic, marxism juridic, raport de drept, raport juridic.
\end{abstract}

* Facultatea de drept a Universității Babeș-Bolyai din Cluj, vpaul@law.ubbcluj.ro 


\title{
LE RAPPORT DE DROIT CIVIL - ÉCHANTILLON IDÉOLOGIQUE VÉCU
}

Bref : Il y a un lieu commun de la doctrine civiliste roumaine d'analyser distinctement le rapport civil et le droit subjectif civil, tout en soulignant que le dernier n'est qu'une partie composante de la relation juridique. La curiosité nous a poussé à chercher les origines de cette vision insolite. C'est ainsi que l'on a entrevu en s'hissant à l'horizon le feu droit socialiste où il faut puiser pour découvrir les racines d'une conception très répandue, reprise et bonne à tout expliquer même aujourd'hui.

Mots-clés : droit civil roumain ; droit civil subjectif ; droit socialiste ; droit soviétique ; marxisme juridique ; rapport de droit ; rapport juridique.

\section{A CASE OF IDEOLOGICAL AND ANALYTICAL NOSTALGIA: THE LEGAL RELATIONSHIP}

\begin{abstract}
It is common to find, in the works of the Romanian civil law authors, an analysis of both the subjective right and of the legal relationship, analysis which compile the first as a meagre element of the last. Curiosity made us search the origins of this rather curios way of reasoning. It is in this manner that we had grasped, in the historical horizon, the dust laid by the blown-out fire of the socialist law towards which we must haste if we want to find the origins of a well-established concept, reused and found to be good at explaining reality, even today: the legal relationship.

Keywords: Romanian civil law, subjective right, socialist law, soviet law, legal Marxism, legal relationship.
\end{abstract}

Cu toții am învățat, iar unii continuă să îi învețe încă și pe alții, că există un raport juridic distinct de dreptul subiectiv. Ar exista, deci, două realităţi juridice diferite - raportul juridic și dreptul subiectiv. Deși un loc comun, afirmația anterioară este totuși eronată. Astfel, nu poate fi depistat un 
raport juridic separat de dreptul subiectiv ${ }^{1}$. Iar explicaţia este dezarmant de simplă - orice drept subiectiv are o natură relațională, adică este chiar raportul juridic. Cu toate acestea, de ce unanim se colportează încă teza falsei dualităţi raport juridic versus drept subiectiv? Și de data aceasta, răspunsul e foarte simplu! Tema dualității raport-drept este creația dreptului sovietic, preluată în România anilor 50, de care nu ne-am descotorosit.

În continuare, vom arunca o privire asupra dreptului României socialiste (1), urmând ca mai apoi să cercetăm starea juridică a României nesocialiste (2).

\section{România socialistă}

„Romania este republică socialistă. În Republica Socialistă România forța politică conducătoare a întregii societăţi este Partidul Comunist Român²", iar ultimul său secretar general a fost tovarășul3 Nicolae Ceaușescu. Cel din urmă nu a făcut decât să îi succeadă lui tov. Gheorghe Gheorghiu-Dej, ambii coordonând efortul de dărâmare a statului român, prin instituirea dictaturii comuniste. Căci „puterea politică este violența organizată exercitată

\footnotetext{
${ }^{1}$ Brevitatis causa, vorbim generic de raporturi (/relaţii) juridice (/de drept), precum și de drepturi subiective, deși nu ne interesează decât cele civile (relații/drepturi). Cu toate acestea, nu ar fi exclus ca unele aspecte să se potrivească oricare ar fi natura dreptului subiectiv în discuție.

${ }^{2}$ Cele două fraze sunt articolele 1 și 3 din Constituția Republicii Socialiste România (RSR) din 1965, care poate fi și găsită $\quad$ la http://www.cdep.ro/pls/legis/legis pck.htp act text?idt=37735.

3 Legea nr. 29/1977 privind normele de adresare în relațiile dintre cetățenii Republicii Socialiste România, publicată în B.of.: 112 din 28.10.1977.
} 
de o clasă pentru asuprirea alteia4". Orice stat socialist este unul ideologic marxism-leninismul fiind singura teorie admisă, iar unicul partid recunoscut, era cel conducător - partidul comunist. Scopul statului socialist a fost edificarea comunismului, prin construirea economiei 5 și a societății socialiste, cu ajutorul dreptului socialist ${ }^{6}$, inspirat nemijlocit și dialectic de gândirea marxist-leninistă7. Orice critică la adresa statului socialist, la ideologia acestuia sau la partidul unic era pedepsită penal ${ }^{8}$. Dreptului socialist era, deci, creația statului „socialist în interesul construirii socialismului și comunismului, care exprimă voința clasei muncitoare aliată cu toți oamenii muncii, iar în perioada de trecere de la socialism la comunism, voința

${ }^{4}$ K. MARX și F. Engels - Manifestul partidului comunist, în K. Marx, F. Engels - Opere alese, vol. I, Editura politică, București, 1966, p. 32.

5 „Esența socialismului este aceasta: toate mijloacele de producție sunt în stăpânirea exclusivă a comunității organizate. Aceasta și numai aceasta este socialism.” Ludwig von Mises Socialismul. O analiză economică și sociologică, citat după https://mises.ro/193/xv-formespeciale-de-socialism. „Țelul socialismului este transferul mijloacelor de producție din proprietatea privată în proprietatea societății organizate, a statului. Statul socialist stăpânește toți factorii materiali de producție și astfel dirijează producția.”, idem, https://mises.ro/18o/iisocialismul.

${ }^{6}$ Copie conformă a dreptului sovietic, care „este un puternic instrument al luptei revoluționare pentru socialism” potrivit lui A. I. Vîșinschi apud I. B. NoviȚCHI, L. A. LuNȚ - Teoria generală a obligațiilor în URSS, Editura de stat pentru literatură științifică, București, 1953 (traducere din rusă de Vera POPESCU și V. RoxAN a lucrării sovietice apărută în 1950, la Moscova), p. 32.

7 I. Demeter, I. CETERCHI - Introducere în studiul dreptului, Editura științifică, București, 1962, p. 14.

8 În perioada 1948-1968, Codul penal reprima crimele de uneltire împotriva ordinii sociale (art. 209), uzurparea ordinii constituționale (art. 207) și răspândirea de manifeste sau publicații interzise (art. 325). După adoptarea Codului penal din 1968 (și până 1989), se pedepsea infracțiunea de propagandă împotriva orânduirii socialiste (art. 166), dar și trădarea (art. 155), cu scopul de a se apăra statul și dreptul socialist, v. T. VÂRȘă, S. IvAN, A. OLARU Infracțiuni contra securităţii statului, ed. MI, Departamentul Securităţii Statului, CIDEditorial, București-1989.

v. https://www.crimelecomunismului.ro/ și https://www.iiccr.ro/resurse/fisele-matricolepenale/detalii-fise-matricole-penale-detinuti-politici/ și http://www.revistamemoria.ro/ 
întregului popor, determinată în ultimă instanță de condițiile vieții materiale ale societății, a cărei respectare și aplicare obligatorie se asigură prin conștiința juridică socialistă a cetățenilor, iar la nevoie cu ajutorul forței coercitive a statului9."

Teoria marxist-leninistă a statului consideră dreptul un element de suprastructură socială, generat (dialectic și istoric) de baza economică a societăţii. „Între raporturile materiale economice şi raporturile juridice ideologice există o strînsă interdependență [...], relațiile economice avînd rolul determinant. Între ele este, în general, acelaşi raport ca între bază și suprastructură ${ }^{10}$.” „Suprastructura juridică, ca și celelalte părți ale suprastructurii, se compune din concepții și instituții” , ,[...] fundamentate pe învățătura marxist-leninistă11", cu scopul construirii socialismului, într-un cadru social în care „,norma juridică este voința clasei dominante, ridicată la rangul de lege $\mathrm{e}^{12}$ ".

Pentru ideologia oficială, societatea era, deci, compusă dintr-o bază cea economică, formată din relațiile de producție, din care cele de proprietate erau esențiale, și o suprastructură ${ }^{13}$ - relații juridice, morale ori artistice ș.a., determinate nemijlocit de economic. Fundamental, categoria de relaţie era cheia teoriei marxiste-leniniste; cu ajutorul ei, se înțelegea și explica întreaga istorie a umanității, societatea şi statul. Marxism-leninismul este o ideologie totalitară, explicând absolut totul prin recursul la noțiunea de raport. Astfel,

9 I. Demeter, I. CETERCHI - op.cit. nota 7, p. 113-114.

${ }^{10}$ Idem, p. 175.

${ }^{11}$ Idem, p. 51.

12 Idem, p. 175.

13 Suprastructura ,e generată de bază, dar aceasta nu înseamnă nicidecum că suprastructura nu face decât să reflecteze baza, că ea este pasivă, neutră”, ci dimpotrivă „,ea devine o forţă activă din cele mai mari”, I. V. Stalin apud I. B. NoviȚCHI, L. A. LuNȚ - op.cit., nota 6, p. 32. 
erau instrumentalizate relațiile economice ${ }^{14}$ - dominate de relații de proprietate, raporturile sociale - determinate de lupta de clasă și pozițiile antagoniste între diverse clase, dar și raporturile juridice. Şi în acest ultim caz, se focaliza discursul pe raporturi, cu efectul că drepturile subiective li se asigurau un rang secund, absorbite deja de raporturile juridice. $\mathrm{O}$ asemenea viziune corespundea întrutotul exigențelor ideologice ale dreptului socialist.

Marxism-leninismul juridic ne explică dialectic ce este cu raportul juridic, care e structura sa, precum și caracterele sale. Raporturile ,juridice pot fi definite ca raporturi de suprastructură, ideologice, condiționate în ultimă instanță, de raporturile materiale, raporturi care se formează pe baza normelor juridice în vigoare și în care participanţii apar ca titulari de drepturi şi obligații juridice reciproce și a căror realizare este asigurată de către stat ${ }^{15}$." Iar în „concepția majorității teoreticienilor dreptului socialist, raportul juridic cuprinde trei elemente: subiectele, conținutul (drepturile şi obligațiile) şi obiectul ${ }^{16 .}$."

„Subiectele raportului juridic sînt legate între ele, tocmai prin aceste drepturi şi obligații, care formează împreună conţinutul raportului juridic ${ }^{17}$." În timp ce „obiectul raportului juridic este acel fenomen asupra căruia sînt îndreptate drepturile subiective şi obligațiile participanților la raportul juridic. Ca obiecte materiale ale raporturilor juridice apar lucrurile (bunurile),

\footnotetext{
14 „Art. 5. Economia națională a României este o economie socialistă, bazată pe proprietatea socialistă asupra mijloacelor de producție. Art. 6. Proprietatea socialistă asupra mijloacelor de producție este fie proprietate de stat - asupra bunurilor aparținând întregului popor, fie proprietate cooperatistă - asupra bunurilor aparţinând fiecărei organizații cooperatiste.”, Constituția RSR din 1965.

15 I. Demeter, I. CETERCHI - op.cit., nota 7, p. 177.

${ }^{16}$ I. CAMENIȚA - Considerații privind noțiunea de obiect al raportului juridic, în Justiția Nouă nr. 9/1965, p. 75-76.

17 I. Demeter, I. CETERCHI - op.cit., nota 7, p. 183.
} 
în raporturile patrimoniale. Obiect al raporturilor juridice mai pot fi diferite valori nepatrimoniale, ca onoarea, libertatea persoanei, creațiile literare, artistice (dreptul de autor). Conduita oamenilor [...] de asemenea poate fi obiect al unor serii întregi de raporturi juridice ${ }^{18}$." Dacă ar fi să ne reamintim caracteristicile raportului juridic socialist, atunci aspectul „volițional şi ideologic al raportului juridic se manifestă, în primul rând, în faptul că raporturile juridice sunt reglementate prin norma juridică ca voință de stat a clasei dominante ${ }^{19} . "$

De unde au sosit aceste idei în doctrina juridică socialistă română ${ }^{20}$ ? Evident, din dreptul sovietic, cel mai avansat din lume! Dreptul sovietic face ca analiza raportului juridic să primeze dreptului subiectiv, după cum îi și trasează liniile esențiale. Iar una dintre cele mai spinoase probleme inventate de sovieticii juriști a fost distincția dintre conținutul și obiectul raportului juridic. Astfel, ,,conținutul raportului de obligație îl constituie, în primul rând, dreptul de a pretinde executarea unei prestațiuni cu caracter patrimonial [...]" şi „conţinutul obligației îl constituie dreptul, facultatea creditorului de a pretinde debitorului să săvârșească (sau să nu săvârșească) anumite acțiuni, şi obligația debitorului de a le săvârşi (sau de a nu le săvârși).” ${ }^{21}$ Adică, drepturile subiective ar intra în conținutul raportului juridic, ceea ce nu scoate totuși din discuție ideea de obiect al unei relații juridice.

„Dacă am exclude noțiunea de obiect, raportul juridic s-ar reduce la drepturi și obligații, care nu s-ar mai știi la ce anume se referă; iar dacă un

${ }^{18}$ Idem, p. 186-187.

19 Idem, p. 174.

${ }^{20}$ Idem, p. 188-189, unde ne sunt înfățișate discuțiile interminabile despre obiectul raportului juridic din dreptul sovietic, cu firave critici (cartea românească apare însă după decesul lui I. V. STALIN ... ).

${ }^{21}$ I. B. NoviȚCHI, L. A. LUNȚ - op.cit., nota 6, p. 69. 
drept nu se referă la nimic, el nu poate avea o valoare reală.”22 „Raportul juridic se transformă într-un schelet [...] dacă, din cadrul lui, eliminăm obiectul asupra căruia poartă drepturile și obligațiile care alcătuiesc conținutul raportului juridic ${ }^{23}$.”, deci, „oricărui raport juridic îi este necesar un obiect, ca element constitutiv al acestui raport ${ }^{24 ”}$ ” „Obiectul raportului juridic este obiectul asupra căruia poartă dreptul subiectului.” „Obiectul unui raport de drept real îl constituie lucrul. Obiectul obligației îl constituie acțiunea a cărei îndeplinire [...] creditorul are dreptul să o pretindă debitorului $25 . "$

Pe cât de fastidioase, pe atât de inutile sunt toate aceste pseudoanalize, cu pretenții științifice ${ }^{26}$, ițite din ideologia sovietică, care considera de altfel dreptul ca o ştiință, iar pe unii juriști, chiar oameni de ştiință. Știința de partid. Dar, primul aspect care surprinde este distincția dintre obiect şi conținut al raportului civil, complet contraintuitivă şi contrară sensurilor cuvintelor folosite (obiect/conținut). Apoi, s-a vădit că distincția operată nu isca decât discuții şi confuzii, îngreunând înțelegerea dialectică a fenomenului juridic. Logic, obiectul ar fi trebuit să fie însuşi conținutul raportului juridic. De ce trebuia să coexiste ambele noțiuni în dreptul socialist? Explicația e simplă - imperativele ideologice marxist-leniniste impuneau o astfel de

\footnotetext{
${ }^{22}$ Idem, p. 54.

23 Idem, p. 55.

24 Idem, p. 58.

25 Idem, p. 58 pg. 7.

26 „Problema obiectului juridic este una dintre cele mai controversate”, suntem avertizați chiar la finele anilor 1980, doctrina românească păstrând aceeași viziune sovietică asupra raportului juridic [v. P. CosmovicI (coord.) - Tratat de drept civil, vol. I, ed. Academiei R.S.R., București, 1989, p. 77]. Toate acestea în ciuda aporiei și a dificultății de a discerne între conținutul și obiectul raportului juridic, iar cele şase opinii despre obiectul raportului juridic sunt reluate în 1989 exact aşa cum erau prezentate cu patru decenii înainte [v. ibidem].
} 
dublare (obiect+conținut). Astfel, obiectul era material, „un fenomen obiectiv $^{27}$ ", care exista independent de conștiința subiectului de drept. Obiectul este simbolul materialității lumii, materia fiind o categorie esențială a materialismului-dialectic - parte a marxism-leninismului, care explica „științific” lumea înconjurătoare. „Materia este categoria filosofică care desemnează realitatea obiectivă, dată omului prin senzațiile lui [...] și existentă independent de ele ${ }^{28}$.” Iar ,„̂n activitatea practică a ajuns omul să se deosebească pe sine ca subiect al acţiunii imediate de obiectul ei imediat și treptat, pe măsura dezvoltării practicii sociale, să capete convingerea deosebirii dintre conştiinţă şi existență în general29.” În consecință, numai „fenomenele lumii obiective (lucrurile materiale, anumite acte de conduită exteriorizate, care s-au desprins de subiect şi anumite valori personalenepatrimoniale) pot constitui obiect al raporturilor juridice ${ }^{30 "}$.

Observăm, obiectul era imperios ideologic necesar ${ }^{31}$ să se regăsească în structura raportul juridic socialist, el asigurând materialitatea acestuia, căci restul era fie subiectivitate (persoanele), fie ținea de suprastructura juridică (drepturile). Obiectul raportului juridic este cadoul pe care marxismleninismul îl face dreptului (socialist).

Dar conținutul raportului? Cum se explică apariția sa şi la ce ar fi servit? Conținutul raportului juridic este identificat, de teoria marxistă, cu dreptul subiectiv, care „nu există decât prin obiectul la care el se referă, căci

27 I. CAMENIȚĂ - op.cit. nota 16, p. 73 .

${ }^{28}$ V. I. LENIN - Materialism şi empiriocriticism, Editura politică, București, 1959, p. 120.

29 A. VAlEntin, V. Flonta (coord.) - Materialism-dialectic, Editura didactică și pedagogică, București, 1982, p. 93.

30 I. CAMENIȚĂ - op cit., nota 16, p. 74 .

31 „Obiectul este un element necesar al raportului juridic.”, idem, p. 75. 
altfel ar însemna să admitem existența unor drepturi fără obiect32”". Alături de acest sofism marxist-leninist debil, amintim că drepturile subiective erau considerate doar simple efecte ale normei juridice edictate de stat, adică fenomene ideologice, ținând de suprastructura juridică. Dreptul socialist nu a reuşit să eradice (nici măcar) din teorie drepturile subiective, dar le-a atârnat de lege, ele existând doar în măsura în care aceasta le recunoștea, cercetarea juridică concentrându-se pe relațiile juridice 33 . Legea socialistă avea un cert caracter de clasă, ținând de suprastructură, ea putând fi modificată de partidul comunist oricând baza economică obiectivă ar fi impus-o. Astfel, se asigura coerență ideologică dorită - obiectul imprimă un caracter obiectivmaterial raportului juridic, iar conținutul acestuia face ca raportul să fie studiat ca element al suprastructurii, unul ideologic și volițional.

Ce ar fi de reținut din toate acestea? Dreptul socialist român (19481989) a fost construit după modelul dreptului sovietic, al cărui epigon zelos sa dovedit, transpunând în teorie și practică ideologia și ordinele partidului comunist. Analiza oficială făcută raportului juridic, a structurii şi caracteristicilor sale, corespundea întocmai învățăturii marxist-leniniste, asumată de teoreticienii statului şi dreptului socialist, care erau pe linie. Adevărat, juriștii nici nu prea aveau de ales, căci toți subiecții de drept trebuiau să gândească la fel - unica teorie ori învățătură oficială fiind

$3^{2}$ Idem, p. 76.

33 Răspunderea civilă nu repara - de pildă, atingerea adusă vreunui drept subiectiv, ci raporturile juridice. „Reglementând raporturile patrimoniale socialiste, dreptul civil sovietic este chemat ca, în cazul că ele ar fi încălcate, să asigure restabilirea acestor raporturi [...].”, O. S. IOFFE - Răspunderea în dreptul civil sovietic, Editura științifică, București, 1956 (în românește de V. STĂTESCU și I. COMȘA), p. 27. 
marxismul-leninist, oricare i-ar fi fost numele curent ${ }^{34}$ ori forma de expresie. După 1990, juriştii puteau alege, delictul de opinie dispărând.

\section{România nesocialistă}

Există azi o ideologie etatică oficială? Nu! Şi mai este limpede că democrația ${ }^{35}$ se întemeiază pe pluripartitism, care e expresia politică a varietății de opinii, teorii sau viziuni existente. Câți juriști marxiști declarați mai există astăzi? Nici măcar unul, căci lipsește orice școală socialistă de gândire, care să își asume fățiş acest caracter. Din inventarul juridic marxistleninist rămâne însă actuală (şi) teoria raportului juridic, preluată integral din dreptul socialist, dar omițându-se indicația sa de proveniență sovietică, şi lipsind vreo asumare ostensibilă a viziunii socialiste despre lume şi viaţă.

Astăzi, raportul juridic „este definit ca o relație socială, ideologică, o relație individualizată, reglementată de norma de drept, apărată de stat și caracterizată prin existența drepturilor și obligațiilor juridice ${ }^{36}$." Încercând lămurirea chestiunii, ni se amintește că raportul juridic este o „legătură

\footnotetext{
34 Marxism, leninism, marxism-leninism, materialism-dialectic, materialism-istoric, socialism științific etc. erau expresii - mai mult sau mai puțin sinonime, care redau (în tot sau în parte) teoria care a fundamentat ideologia oficială a statelor socialiste, conduse de partidul comunist unic. Nu este aici locul să facem distincție nici între aceste expresii, nici între filozofia, ideologia şi propaganda (toate) comuniste.

35 „România est stat de drept, democratic și social, în care demnitatea omului, drepturile și libertățile cetățenilor, libera dezvoltare a personalității umane, dreptatea și pluralismul politic reprezintă valori supreme, în spiritul tradițiilor democratice ale poporului român și idealurilor Revoluției din decembrie 1989, și sunt garantate.”, art. 1 alin. (3) din Constituția României din 1991.

${ }^{36}$ N. PopA - Teoria generală a dreptului, ed. Actami, București, 1998, p. 294 [identic cu N. PoPA - Teoria generală a dreptului, ed. C. H. Beck, București, 2014, p. 217]. În același registru, v. G. Bовоș - Teoria generală a dreptului, ed. Argonaut, Cluj, 1999, p. 272 și urm.
} 
socială, reglementată de norma juridică, conținând un sistem de interacțiune reciprocă între participanți determinați, legătură ce este susceptibilă a fi apărută pe calea coercițiunii statale 37 ". Toți autorii ${ }^{38}$ de drept civil nu văd în raportul juridic civil 39 decât o specie de raport de drept. Această relație juridică este înțeleasă „ca fiind acel raport social care este reglementat de normele dreptului civil40”, accentul căzând pe ideea că raportul devine juridic în prezența „unei norme juridice care reglementează acel raport ${ }^{41}$ ”. Este, deci, un loc comun actual să se evidențieze raportul civil ca o entitate distinctă de drepturile subiective (civile), care intră (îndeobște) în conținutul acestui raport. Efectul discursiv este că se analizează distinct și izvoarele raportului civil de cele ale drepturilor subiective, estompându-se totuși cu această ocazie diferența dintre raport și dreptul subiectiv. Am identificat mai sus care e sursa acestei deosebiri, pe care analitic o găsim greșită de îndată ce integrează în conținutul raportului însuși dreptul subiectiv. Raportul civil nu e distinct de dreptul subiectiv, ci însuşi dreptul, pe care îl exprimă relațional.

Marcând net diferența raport civil versus drept subiectiv civil şi subliniind că legătura dintre cele două ar fi de la întreg (raportul) la parte (dreptul), teoria actuală a dreptului civil se desparte de cea anterioară lui

37 N. PoPA - op.cit., nota 26, p. 294.

$3^{8}$ G. Boroi, C. A. ANGHELESCU - Curs de drept civil. Partea generală, ed. Hamangiu, București, 2012, p. 51; E. CHELARU - Teoria generală a dreptului civil, ed. C. H. Beck, București, 2014, p. 46; M. NiCOLAE - Drept civil. Teoria generală, Vol. II. Teoria drepturilor subiective civile, ed. Solomon, București, 2018, p. 2; O. Ungureanu, C. Munteanu - Drept civil. Partea generală, ed. Universul Juridic, București, 2017, p. 109.

39 Tautologia expresiei „raportul juridic civil” este patentă, devenind un loc comun.

40 I. Reghini în Reghini, Ș. Diaconescu, P. Vasilescu - Introducere în dreptul civil, ed. Hamangiu, București, 2013, p. 60. Iar mai jos, autorul, nuanțându-și poziția, ne spune că „raportul juridic civil este relația care rezultă din acele împrejurări cărora normele dreptului le conferă calitatea de fapte juridice civile (izvoare ale raporturilor juridice civile)”, idem, p. 62. ${ }^{41}$ Idem, p. 60. 
1948. Ceea ce îi interesa pe autorii interbelici nu era să disjungă raporturile juridice de drepturile subiective civile, ci să definească aceste drepturi şi să le clasifice, exprimând varii probleme specifice, legate de concepțiile dezbătute deja în spațiul cultural Occidental ${ }^{42}$. Pentru acești doctrinari români, fie raporturile juridice erau prezentate ca plenitudine a drepturilor civile subiective, în sens analitic şi practic; de pildă, când se voia sublinierea ideii că o creanță nu există fără corelativul ei - obligația43; fie raporturile erau sinonime cu drepturile subiective, despre care se discuta44. In toate cazurile, nu am identificat nicio analiză care să considere raportul juridic ca fiind altceva decât dreptul subiectiv, după cum nu am remarcat nici teoretizarea structurii raportului civil, cu ideea aferentă că acesta ar îngloba dreptul subiectiv în conținutul său. Ultimele două aspecte teoretice rămân un loc comun al dreptului socialist, pe care deja l-am înfățișat.

În consecință, și astăzi, se afirmă unanim ${ }^{45}$, că raportul civil este diferit de dreptul subiectiv, care nu ar fi decât o componentă structurală a acestui

42 Cel puțin în spațiul de expresie franceză, efervescența teoretică era alimentată de identificarea și definirea drepturilor subiective (civile), elementul relațional al dreptului nefiind (de regulă) nici negat, dar nici autonomizat. În acest sens se pot circumstanția eforturile lui Duguit, Ihering, Kelsen, Dabin etc., v. J. Ghestin, G. Goubeaux, M. Fabre-Magnan - Traité de droit civil. Introduction générale, ed. LGDJ, Paris, 1994, p. 126; J. DABIN - Le droit subjectif, Dalloz, Paris, 2008, p. 5.

43 M. DJUVARA - Despre teoria izvoarelor raporturilor juridice şi a cauzalităţii în drept (apărut inițial în 1942), în M. DJUvARA - Teoria generală a Dreptului. Drept rațional, izvoare şi Drept pozitiv, ed. All, București, 1995, p. 119.

44 e.g. M. B. CANTACUZINo - Elementele dreptului civil, (apărut inițial în 1921), ed. All, București, 1998, p. 24; C. HamangIU, I. RosetTI BăLĂNeSCU, Al. BăICOIANU - Tratat de drept civil român, vol. I, (apărut inițial în 1928), ed. All, București, 1996, p. 526; I. MICESCU - Curs de drept civil, (predat în anii 1931-1932), ed. All Beck, București, 2000, p. 98.

45 G. Boroi, C. A. ANGHELESCU - op.cit., nota 38, p. 51; E. Chelaru - op.cit., nota 38, p. 45; M. Nicolae - op.cit., nota 38, p. 2; O. Ungureanu, C. Munteanu - op.cit., nota 38, p. 110; I. REGHINI - op.cit., nota 40, p. 62, n. 1 ; p. 73 . 
raport, concretizată în conținutul raportului civil. Astfel se şi închide bucla analitică, deschizându-se discuția despre structura raportului, care cuprinde subiecții, un conținut și un obiect.

În fond, nu e nicio eroare să discuţi despre raporturi de drept civil, dacă astfel se subliniază ideea că în lipsa unui drept subiectiv nu există raporturi juridice. Însă, nu avem de-a face aici cu o relație de tipul întregparte. Raportul nu este întregul, iar dreptul nu e parte, o simplă componentă a acestuia. Dreptul subiectiv este singurul întreg, conferind sens analizei raportului, care nu e decât manifestarea socială a dreptului. Dreptul subiectiv este cel care are o structură internă, care analitic poate fi împrumutată raportului, tocmai pentru că orice drept subiectiv este un raport, o relaţie socială. Nu există distincție categorială, raportul juridic nu este o altă noțiune sau categorie juridică decât dreptul subiectiv. Nu există nici deosebire tehnică între raport și drept; primul nu este întregul, iar cel de-al doilea nu este doar partea, ori conținutul relației.

Dacă asemenea distincții ar fi întemeiate, atunci ar trebui să existe inclusiv drepturi subiective non-relaționale, simple obiecte prinse într-un păienjeniș social. Însă, în dreptul actual, nu există drepturi subiective care să nu fie relații. Iar aceste relații se concretizează într-un aspect simplu: dreptul subiectiv este un comportament, o conduită interumană garantată și sancționată juridic. Dacă proprietarul unei case vrea să o vândă, el transferă dreptul său unui alt subiect, intrând în raporturi juridice concretizate de dreptul său de proprietate și de creanțele generate de actul de vânzare. În afara drepturilor subiective, vânzarea nu produce alte efecte juridice; nu există alte relații juridice între proprietar și cel care cumpără casa, decât drepturi lor subiective care îi leagă. În fine, dacă acelaşi proprietar vrea numai 
să folosească pentru sine casa, raporturile sale cu ceilalți sunt juridic prinse în dreptul său real (de proprietate).

Raportul de drept civil este sinonim cu drepturile subiective civile. Un raport juridic este o legătură socială, unind subiecții de drept, prin efectele drepturilor civile care sunt deja stabilite între aceștia. Orice drept subiectiv civil are o natură relațională mai mult sau mai puțin evidentă, care se concretizează într-un raport interuman special, deosebit de relațiile nonjuridice. Există raporturi umane întemeiate pe sentimente, pe conivențe sociale, pe etică ori pe tradiții, ele neavând un scop sau un sens juridic, deși toate contribuie la ordinea socială. Aceste raporturi nu privesc drepturi subiective, după cum nu intră sub incidența dreptului civil obiectiv, deși toate sunt relații sociale. Prin urmare, a discuta despre raporturile juridice civile înseamnă a analiza doar drepturile subiective, existente (teoretic ori practic) la un moment dat. Simplificând, de pildă, dacă o persoană închiriază un autoturism de la o societate de profil, se naște un raport civil în temeiul căruia chiriaşul trebuie să plătească suma convenită (chiria) societății în schimbul folosinței lucrului. Acest raport este de jure o creanță ${ }^{46}$, un drept subiectiv aparţinând societăţii, care va fi valorificat (executat) amiabil sau silit în raport cu chiriaşul. În lipsa drepturilor subiective, care îndreptățesc social la un anumit comportament juridic pe titularii lor, nu există niciun raport de drept.

\footnotetext{
${ }^{46}$ Creanța descrie un raport de tête à tête juridic, subiecții văzându-se de aproape, unul având pretenția la ceva de la celălalt. Astfel, titularul dreptului subiectiv, parte a legăturii juridice creditorul, e îndreptățit să ceară celeilalte părți a raportului un anumit comportament juridic - obligația corelativă a debitorului. Instantaneu, creanța este și drept (pentru creditor) și obligație (pentru debitor), ceea ce se poate explica numai prin natura sa relațională. Deci, prin creanță se desemnează, în funcție de context, un drept subiectiv, un raport juridic în ansamblul său ori chiar obligația civilă, privită din perspectiva juridică a creditorului.
} 
Raporturile juridice civile devin patrimoniale atunci când ele sunt drepturi reale sau de creanță, acest domeniu fiind cel predilect al dreptului civil; ambele cuprinzând întreaga sferă economică (civilă). Exemplele date mai sus intră în această categorie, ele referindu-se fie la creanțe, fie la proprietate. Raporturile pot fi extrapatrimoniale când luăm în considerare doar drepturi ale personalității umane și elemente de identificare a persoanei. Împărțirea ar trebui să fie ideală și fără rest, practic totuși nu este exclusă și o interferare, o condiționare reciprocă ori chiar o contaminare reciprocă. Dualitatea umană corp-suflet dă încă bătăi de cap metafizicienilor, psihologilor şi medicilor, dar nici dreptul civil nu e scutit de aporii, dualismul bun-persoană asigurându-i încă suficientă combustie ideatică, prin contrariile care se atrag respingându-se.

Raportul de drept nu este, deci, o categorie juridică autonomă, ci expresia, înfățişarea dinamică a oricărui drept subiectiv, singura entitate și categorie distinctă și importantă în această analiză. Raportul subliniază legătura juridică ce există între titularul dreptului și celălalt (/ceilalți), accentuând ideea că orice drept subiectiv este în fond un comportament juridic. Static și unilateral, dreptul are sens și i se explică titularului său ca o potențialitate juridică proprie ${ }^{47}$. Dinamic și bilateral, dreptul ni se prezintă ca un raport, o legătură, o interacţiune juridică între subiecți, în urma căreia titularul dreptului își materializează48 ${ }^{8}$ potențialitatea juridică.

Acum, nu ne preocupă să definim ori să analizăm aici drepturile subiective civile, ci să ne referim la unele aspecte care ne sunt înfățişate

\footnotetext{
47 Creanța e (şi) prestația promisă, pe care creditorul o va putea obține de la debitor.

48 Raportul de creanță înfățișează ideea că debitorul este acela care trebuie să facă ceva (dare, facere, non facere) în folosul creditorului, împlinindu-se astfel potențialitatea dreptului de creanță aparținând titularului.
} 
îndeobște atunci când se abordează raportul civil - structura (2.1) și trăsăturile sale (2.2).

\subsection{Structura raportului de drept civil}

Structura raportului de drept civil este însăşi structura dreptului subiectiv pe care îl înfățișează. De aceea, dacă încă vorbim despre structura, caracterele sau clasificarea raportului juridic, va trebui să înfățişăm nu altceva decât structura, caracterele sau clasificarea dreptului subiectiv (civil). Astfel, subiecții, conținutul și sancțiunea ar caracteriza orice raport de drept (subiectiv).

Subiecții raportului sunt părțile acestuia, adică titularii drepturilor și obligaților civile prinși într-o relație juridică (concretă). Subiecții sunt întotdeauna persoane, pentru că raporturile juridice fiind sociale, ele se stabilesc exclusiv între persoane. Acestea sunt concret fie indivizi umani, numiți în jargonul civil persoane fizice, fie persoane juridice (morale), adică structuri organizate şi dotate cu capacitatea de a avea drepturi şi obligaţii civile (societăți, regii, asociații etc.). În general, pentru caracterizarea teoretică a raportului juridic puțin contează că avem de-a face cu o persoană fizică sau cu una juridică. Raporturile civile nu se pot stabili între oameni şi lucruri sau față de animale, pentru că cele din urmă nu sunt decât bunuri, entități structural și funcțional distincte de persoane. Categoria restrictivă și închisă este cea a subiecților de drept, căci numai aceștia pot fi actori sociali, restul fiind bunuri sau lucruri, lipsite de subiectivitate juridică. Uneori, acest aspect poate fi umbrit chiar de specificul sau dinamica dreptului subiectiv.

Există riscul unei asemenea confuzii mai ales în ipoteza drepturilor reale, şi în special în cazul proprietății, care ar lăsa impresia că legătura definitorie există între un subiect și un obiect: proprietarul ară ogorul pe care 
îl are ori se plimbă cu motoreta sa. În adevăr, nu este vorba aici decât de exercițiul dreptului (de proprietate), nu de definirea lui. Aceasta se face juridic acum prin excluziune: nimeni altul nu are puterea să are acel ogor ori să conducă acea motoretă. Specific drepturilor reale este că ele au nevoie de bunuri (re), dar definirea acestora se face prin intermediul puterilor [care se pot exercita asupra lor] în raport cu ceilalți; puteri sau facultăți ori posibilități care sunt opuse de titular celorlalți, aceștia fiind ținuți de jure să le respecte. La drepturile reale, bunurile se interpun între oameni. La creanțe, totul pare mai clar, subiecții fiind față-n față: creditorul (subiectul activ) are posibilitatea să comande direct debitorului (subiect pasiv) un comportament determinat, ceea ce reliefează dimensiunea interumană a raportului de creanță.

Conținutul ${ }^{49}$ raportului de drept este dat de atitudinea juridică la care sunt îndreptățiți sau ținuți subiecții acelei legături juridice. Este vorba, deci, de comportamentul concret al subiecţilor, care este precizat exact de natura și caracteristica dreptului subiectiv deținut de aceștia. Dacă discutăm de creanțe, creditorul poate solicita să i se dea (dare) sau facă (facere) ceva anume ${ }^{50}$, iar debitorul trebuie să se conformeze exact, dând ori făcând ceea ce i se cere. Dacă privim la drepturile reale, proprietarul ${ }^{51}$, de pildă, e îndrituit să folosească şi să dispună de bunul său, ceilalți fiind excluşi de la aceste posibilități şi trebuind să respecte acțiunile titularului. Conținutul raporturilor extrapatrimoniale este oglindit de ceea ce anume poate solicita

\footnotetext{
49 Repetăm: am renunțat la ideea de obiect al raportului, identificat chiar cu comportamentul titularilor de drept subiectiv, de cei care susțin dualitatea raport juridic - drept subiectiv. Dorința noastră este de a nu dubla inutil dreptul subiectiv cu un alt raport (juridic), care e în fond inexistent, dar persistent din inerţie analitică.

$5^{0}$ Este vorba de obiectul obligației, denumită curent prestație, v. art. 1164 și 1226 C. civ.

${ }^{51}$ Art. 555 C. civ. este chiar intitulat „conținutul dreptului de proprietate privată”.
} 
sau exercita de jure titularul dreptului. De exemplu, persoana poate fi legitim identificată juridic purtând un anumit nume - pentru dreptul la nume, sau poate cere să fie tratată ca având filiația pe care o exhibă, ceilalți neputând să adopte exact acelaşi comportament ${ }^{52}$, sub amenințarea unei sancțiuni (inclusiv civile).

Sancțiunea civilă este și ea prezentă53, deși nu întotdeauna evidentă. Sancțiunea asigură valorificarea dreptului civil pe cale silită ori restabilirea situației anterioare momentului în care dreptul este nesocotit. Atunci când debitorul nu vrea să plătească de bunăvoie, o va face silit de executorul judecătoresc; când un bun este distrus sau avariat, proprietarul e îndreptățit la reparație; când se aduc atingeri drepturilor personalității, cel vexat e îndrituit să ceară stoparea acțiunilor și repararea daunelor etc. Sancțiunea garantează eficacitatea juridică a dreptului. Astfel se și face diferența față de alte legături sociale (de prietenie, de curtoazie, morale); de regulă, sancțiunea este etatică și se înfăptuiește organizat. Nimeni nu are dreptul să își facă singur dreptate, pentru aceasta existând organe judiciare, care pun în operă mecanismele de constrângere și de sancționare. Uneori se vede în sancțiune chiar diferența fundamentală care separă raporturile juridice de cele morale,

$5^{2}$ Să poarte un nume identic ori să pretindă aceeași filiație. Evident, în caz de conflict, există reguli după care se rezolvă situația în care mai mulți subiecți ar avea pretenția de a deține acelaşi drept (patrimonial sau nu).

53 Discuțiile despre sancțiune repugnă în general civiliștilor, considerând că dreptul privat are suficientă energie ca să se impună de la sine. Oricum, chestiunea e controversată, un noian de întrebări sufocând răspunsurile firave. E consubstanțială sancțiunea dreptului subiectiv sau e survenită și exogenă? Executarea (silită) face din obligații altceva decât erau $a b$ initio? Sancţiunile adevărate sunt doar cele etatice? Cât de departe se poate merge cu sancțiunea privată? Limpede însă, criteriul (cel puțin) empiric al distincției dintre situațiile juridice și cele non-juridice este cel al dreptului subiectiv, care rămâne eficient de jure prin sancţiunea sa. Locatorul amintit mai sus are (și) o acțiune civilă contractuală, pentru recuperarea mașinii închiriate; părintele nu își închiriază mașina fiului, ci îi îngăduie de facto să o folosească, având (in extremis) totuși o acțiune, dar nu întemeiată pe vreo creanță. 
alteori se atașează sancțiunea numai normei juridice. Cert însă, fără sancțiune, raporturile juridice nu ar avea putere de jure, iar comportamentul subiecților ar deveni arbitrar, sustrăgându-se după bunul lor plac de la îndatoriri și obligații. În civil, sancțiunile nu sunt chiar pedepse, căci nu au un caracter personal și aflictiv, nu sunt concepute să lovească în persoană - ca în materie penală -, ci sunt patrimoniale, ducând la scăderi ale avutului acesteia.

\subsection{Trăsături}

Şi astăzi, când se preferă disjungerea teoretică a drepturilor subiective de raporturile de jure pe care acestea le înfățișează, se amintesc 54 inclusiv particularităţile raportului civil. Astfel, ca un fel de numitor comun, se consideră definitoriu pentru raportul civil poziția de egalitate existentă între subiecți, natura volițională a relației juridice, precum și caracterul său social. Sunt însă aceste caracteristici, evidențiate de dreptul socialist, cele care fac diferența între dreptul civil și oricare alt drept subiectiv, fiind ele într-adevăr specifice doar legăturilor juridice civile?

Tot ceea ce se întâmplă în drept este şi (fapt) social, în sensul că în discuție sunt întotdeauna raporturi umane, care descriu o rețea socială. Nimic nu poate fi în afara societății, a legăturilor sociale, cât timp se discută despre drept, indiferent dacă e vorba de cel public ori de dreptul privat. Funcţional și structural, dreptul este un fenomen social şi nu are sens decât raportat la oamenii trăind într-o societate dată şi indiferent dacă ne referim la organizarea ei politică sau la structurile sale civile. Intelectual, dreptul este cert un produs cultural, dar nici acum nu poate fi izolat de social, căci el

54 G. Boroi, C. A. ANGHELESCU - op.cit., nota 38, p. 51; E. ChelARU - op.cit., nota 38, p. 45; M. Nicolae - op.cit., nota 38, p. 3; O. Ungureanu, C. MunTEANU - op.cit., nota 38, p. 110; I. REGHINI - op.cit., nota 40, p. 62, n. 1; p. 73. 
reflectă nivelul de înțelegere a relațiilor de forță dintre oameni. Orice raport juridic e social, deci, nu numai cel civil ori de drept privat ar fi o relație socială. Statul însuşi e un nod relațional, o realitate relațională de jure, care permite organizarea modernă a societății juridice. Dreptul subiectiv civil este și el un raport social de putere juridică. Dreptul ca obiect nu există.

Natura volițională a raportului de drept civil, a drepturilor sale subiective, se poate justifica doar dacă discutăm despre contract; acesta ocupând o parte (normativă şi practică) importantă a civilului, dar totuşi numai o porțiune. Existența faptelor juridice, care nu valorifică voința de a crea dreptul și a evenimentelor ca surse de drepturi subiective, este dovada apariției unor raporturi civile care nu datorează nimic voinței subiecților de drept. În plus, dacă prin volițional s-ar înțelege voința legiuitorului, cu efectul că norma juridică ar fi un act de voință, ceea ce ar imprima un caracter volițional raportului civil, atunci ar trebui admis că absolut toate relațiile juridice (civile sau nu) sunt voliționale, pentru că toate sunt organizate, regularizate de norme de drept. Deci, nu numai legăturile juridice civile ar fi voliționale. În fine, prezentarea legii sau a normei juridice ca un act de voință nu este decât o opinie, una inspiratăs5 de voluntarismul juridic derivat inițial din teoria contractualismului (social). Există însă şi multe alte variante ori viziuni despre sursa normei de drept: suveranitatea, procedura de adoptare, starea de excepție, automatismul instituțiilor decidente, inspirația divină, ordinea în sine a lucrurilor etc.

55 Teoria socialistă înțelegea dreptul (obiectiv) ca un element de suprastructură socială, el imprimând un caracter voliţional raportului de drept (civil). Marxismul juridic nu are nicio legătură cu contractualismul, ci cu voluntarismul antagonist, adică cu voința de clasă - legea fiind dreptul (obiectiv), adică voința clasei muncitoare, v. supra, România socialistă. 
Egalitatea subiecţilor este considerată tradițional și ea ca fiind o caracteristică esențială a raportului civil şi - prin expandare, o trăsătură chiar a întregului sistem normativ civil. Poziția de egalitate s-ar referi, în dreptul obiectiv civil, la ideea că nu există o relație de subordonare apriorică între subiecții civil, că niciunul dintre aceștia nu poate comanda juridic altuia. Subordonarea juridică ar fi o constantă a dreptului public, în special al celui administrativ, cu care se compară uneori civilul, unde principial e consacrată inegalitatea, în sensul de supunere juridică̌ ${ }^{6}$. Trăsătura ar fi impusă de însăşi natura actelor administrative care, fiind unilaterale, trebuie executate de destinatari, impunându-se ca un ordin ${ }^{57}$ acestora. Deciziile, dispozițiile ori hotărârile administrative se emit ad nutum, pentru că ele sunt acte date în exercițiul puterii publice, concretizând în ultimă instanță un interes general. Toate acestea sunt adevărate, dar nu ar trebui exagerat. Chiar și în dreptul public, principiul subordonării a devenit mai maleabil ori chiar pus în discuție prin promovarea altor reguli, cum ar fi aceea a colaborării dintre instituții, a participării plebiscitare la luarea deciziilor în materie de politici publice etc.

În dreptul civil, egalitatea ar trebui înțeleasă mai curând ca o egalitate de şanse juridice, existentă aprioric, de principiu. Fiecare subiect de drept se supune aceluiași regim juridic, identic pentru toți, putând folosi orice mijloc

\footnotetext{
56 Aceasta nu înseamnă că în materie de administrație publică nu există raporturi de colaborare, după cum chiar ideea de subordonare e uneori expres exclusă; de pildă, primarii nu se subordonează prefecților [art. 123 alin. (4) din Constituție]. Principial, lipsa de egalitate juridică administrativă este prezentă fie în raporturile verticale, stabilite între organe distincte (e.g. ministerele comandă agențiilor care sunt în subordinea lor); fie în raporturile de impunere a efectelor actelor administrative (e.g. trebuie construit exact cum se precizează în autorizația de construire; se execută amenda stabilită prin procesul-verbal contravențional necontestat; se plătește impozitul stabilit prin decizia de impunere).

57 O. PoDARU - Drept administrativ. Vol. I Actul administrativ, ed. Hamangiu, București, 2010, p. 14.
} 
juridic civil, potrivit interesului propriu. Aspectul e concretizat în categoria capacității de folosință. Aceasta este generală și identică pentru toți indivizii, indiferent de sex, rasă, etnie, religie, vârstă etc., permițând virtual oricui să aibă orice drept subiectiv civil. În al doilea rând, egalitatea, în dreptul civil, exclude existența privilegiilor $5^{8}$, adică a favorurilor juridice speciale concedate numai câtorva persoane şi doar pentru că ele fac parte dintr-o anumită categorie socială, cum era curent în societatea premodernă. Astăzi, toți subiecții de drept, indiferent de numele şi structura lor, pot deveni titulari ai drepturilor subiective care conferă oricui aceleaşi posibilităţi juridice, ele fiind concepute identic pentru noi toți. În al treilea rând, niciun subiect de drept civil nu are la dispoziție mijloace proprii şi exclusive de constrângere a celuilalt. Dacă drepturile civile sunt încălcate ori obligațiile nu sunt executate, cel îndreptățit va apela la mijloacele juridice de constrângere aflate la dispoziția oricui, fără discriminare şi fără să existe vreun privilegiu de jurisdicție59.

În fine, egalitatea civilă capătă un sens aparte ${ }^{60}$ când ne referim la convenții, unde - înainte de a încheia un contract -, de principiu, subiecții sunt plasaţi pe aceeaşi treaptă juridică, niciunul neputându-şi impune

\footnotetext{
$5^{8}$ Nominal, privilegiile mai există în dreptul civil, dar acestea sunt ataşate de creanțe, nu de persoane, având scopul de garanții ale executării obligațiilor. Dincolo de nume, nu există nicio legătură între privilegiile de statut personal și privilegiile accesorii creanțelor, v. art. 2333-2342 C. civ.; P. VASILESCU - Drept civil. Obligații, ed. Hamangiu, București, 2017, p. 149.

59 În dreptul public, actul administrativ e de regulă un titlu executoriu ope legis, iar contenciosul administrativ conferă o poziție privilegiată Administrației (O. PODARU - op.cit. nota 57, p. 20 și 29), ceea ce nu se întâmplă în dreptul civil.

60 Uneori, se vorbește și de „reguli speciale de egalitate” (J. CARBOnNIER - Droit civil. Introduction. Les personnes. La famille, l'enfant, le couple, ed. PUF, Paris-2004, p. 521), pentru a se desemna aplicații ale egalității în anumite materii precise, cum ar fi egalitatea creditorilor chirografari (art. 2326 C. civ.) ori egalitatea succesorală existentă între rudele de același grad care compun aceeași clasă de moștenitori (art. 964 C. civ.).
} 
discreționar voința celuilalt. Ideal ${ }^{61}$, contractul este domeniul predilect al egalității civile a subiecților, el fiind rezultatul voinței juridice egale a părților sale, care convin reciproc la concesii juridice.

Egalitatea rămâne un deziderat şi un principiu al dreptului (privat), ceea ce nu înseamnă că excepțiile ar lipsi, că discriminările nu sunt impuse chiar de lege lata ${ }^{62}$. Inevitabil, echilibrul ideal dintre subiecți se rupe practic, iar la aceasta contribuie însuşi dreptul civil și viața economică. Astfel, tocmai drepturile subiective civile pot fi înțelese, atunci când sunt efective, ca mijloace de discriminare legitimă, de stabilire a unei stări juridice de inegalitate îndreptăţită. Într-o relație de jure, creditorul nu este egalul debitorului, ultimul fiind ținut să aibă comportamentul pretins de titularul creanței; proprietarul nu este egalul stăpânului în fapt al bunului, căruia poate să-i ceară încetarea actelor de folosință ilegală asupra lucrului; o persoană căsătorită nu mai este egala uneia celibatare, fiind ținută de o seamă de îndatoriri63: de fidelitate, de domiciliu comun conjugal, de sprijin şi întreținere al celuilalt soț etc. Egalitatea civilă e una ideală şi principială. Ea permite ca dreptul civil să producă constant acelaşi efect juridic oricare ar fi subiectul concret în cauză. Egalitatea civilă e una inițială, opunându-se discriminărilor juridice nejustificate sau întemeiate pe un statut social

\footnotetext{
${ }^{61}$ Practic, contractele de adeziune şi cele forțate nu sunt acte negociate, ele sfidând principiul egalității.

62 Dreptul consumului stabilește regula că o parte a contractului de consum este (mai) slabă, cealaltă fiind profesionistă și ținută de mai multe obligații [P. VASILESCU (coord.) Consumerismul contractual. Repere pentru o teorie generală a contractelor de consum, ed. Sfera juridică, Cluj, 2006], iar în dreptul succesoral sunt favorizate firesc rudele de grad mai apropiat de de cujus, raportat la cele de rudenie mai îndepărtată, având legal fie o cotă mai mare succesorală, fie drepturi speciale (cum e rezerva succesorală).

63 E. FlORIAN - Căsătoria. Regimuri matrimoniale. Filiația, ed. C. H. Beck, București, 2016, p. 90.
} 
preferențial. Iar dacă egalitatea este înțeleasă ca una în fața legii, atunci cu atât mai puțin se justifică ca ea să constituie astăzi un criteriu exclusiv al dreptului civil, al raportului civil.

\section{$3 \quad$ Concluzia?}

Raportul de drept civil există şi este identic cu dreptul subiectiv (civil). Cel din urmă nu poate fi o simplă componentă a raportului de drept, ci chiar originea și numele acestei legături de jure. Observam că disjuncția profesată între raport şi drept a implicat analitic inclusiv ideea întâietăţii legăturii juridice, imposibilă însă logic, în absența dreptului subiectiv. Privilegierea raportului față de dreptul subiectiv a fost practicată de dreptul sovietic şi preluată inclusiv la noi, sursa sa ideologică fiind ignorată, în ultimele decenii. În fine, miza legăturii dintre raport şi drept nu este chiar pur tehnică, ci de poziționare teoretică. Ca să găsim tăria de a ne despărți de trecut râzând, ar trebuie să avem puterea să-l înțelegem, altfel îl vom repeta ori regreta. 